The only respect in which I would take issue with this book is that it gives insufficient recognition, at least explicitly, to the differences in the core skills that are often referred to as the DNA of each protagonist.

Microsoft's success is founded in its ability to manage the accurate and detailed compilation of an extensive set of technical standards that facilitate interoperability and technical integration between different applications, mostly for the benefit of those with complex tasks to undertake. Google's success is based on a much deeper understanding than Microsoft of the value of data and how data can be linked and remodelled to maximize predictive decisioning. Apple by contrast reads from this account as an organization in the image of a person who harnessed technological adaptability with a restless search for the most satisfying user experience, most often for a person who sought pleasure from applying an elegant sophistication to tasks that were immediate, not necessary essential and often leisure based.

Richard Webber Hon F IDM

\title{
Changing the world is the only fit work for a grown man: An eyewitness account of the life and times of Howard Luck Gossage - 'Sixties America's most ... influential and irreverent advertising genius
}

Steve Harrison

Adworld Press, 2012; £11.99, 208pp., ISBN-10: 0957151500; ISBN-13: 978-0957151505 (Paperback)

Journal of Direct, Data and Digital Marketing Practice (2012) 14, 86-87. doi:10.1057/dddmp.2012.16

I have just read the most compelling book that I have encountered for many years. Writing a 600-word review is not easy because 2,000 would barely do it justice.

The book is 'Changing the world is the only fit work for a grown man' by Steve Harrison.

\section{A true 'one-off'}

It's the story of a true 'one-off' in the advertising business. The word genius is bandied about too easily, but in the case of Howard Luck Gossage it really is the only word that fits.

This is a man who invented social networking, interactive advertising, pay per view media, media independents, PR events and more, all 30 or more years before they happened on a broad front.

He was not always popular with his contemporaries, advocating as he did that the commission system of payment for advertising agencies was wrong because 'bad ads earn more than highly efficient ones', that is, they had to be run more often to achieve the same result.

He resigned one of his major accounts because although the client was happy with the advertising Gossage wasn't — clearly a man of huge integrity. 


\section{Come and get me Copper}

\section{Free 'Pink Air'}

\section{A delight to read}

Gossage would often run an ad once only, invite response, and wait for the dialogue to develop before running another if necessary. (What fun he would have had with today's pay per click advertising!) And a second ad was not always necessary. Many of his ads were so original that even though they were run solely in the New Yorker they transcended continents - witness the story of The 1st International Paper Airplane Competition - the book is worth the price for this campaign alone.

Or my personal favourite, the Eagle Shirts campaign that instead of simply parading the available range, offered a prize to the reader who suggested the most imaginative new colour. There were so many good ones, but 'Come and get me Copper' would have won the prize had I been the judge. Run only in the New Yorker, the story was picked up by The Times here and reportedly generated 4,000 suggestions from UK readers alone! Sometime later Ford copied the idea to generate dialogue with their own customers.

One of the tenets advocated by David Ogilvy and many of his followers, including me, is 'humour doesn't sell'. But Gossage knew his audience - how else could he make the following headline work?

'If you're driving down the road and you see a Fina station and it's on your side so you don't have to make a U-turn through traffic and there aren't six cars waiting and you need gas or something — please stop in'.

As with all his ads there was a coupon, this time offering a free pink valve cap. This and his spurious offering of 'Pink Air' helped Fina expand from 500 to more than 3,000 stations. His premise was simple - all brands of gasoline are the same so let's make the motorists like us.

Gossage was also a grand master of PR, getting many clients immense free coverage for his ideas.

In between writing ads he found time to launch Marshall McLuhan (the medium is the message), start the green movement — his campaign to prevent the Grand Canyon being dammed was one of his many successes - and name Friends of the Earth.

There are two ways of tackling a biographical work:

1. Copious desk research, which can sometimes result in an acceptable job, or

2. Painstaking, time-consuming personal interviews with the subject's contemporaries.

Steve Harrison took the latter route and he has produced an authentic eye-witness picture of a man who changed the lives of the many people he touched. It is also very well written and thus a delight to read.

I defy anyone in our business to read this book and not come away inspired and much better informed.

Howard Luck Gossage - a hell of a man; a hell of a book!

Buy it today — you will not be disappointed! 